\title{
Hyperinsulinaemic Hypoglycaemia: Genetic Mechanisms, Diagnosis and Management
}

\author{
Zainaba Mohamed, Ved Bhushan Arya, Khalid Hussain \\ University College London, Institue of Child Health, Developmental Endocrinology Research Clinical, \\ Molecular Genetics Unit, London, United Kingdom
}

\begin{abstract}
Hyperinsulinaemic hypoglycaemia $(H H)$ is characterized by unregulated insulin secretion from pancreatic $\beta$-cells. Untreated hypoglycaemia in infants can lead to seizures, developmental delay, and subsequent permanent brain injury. Early identification and meticulous managementof these patients is vital to prevent neurological insult. Mutations in eight different genes (ABCC8, KCNJ11, GLUD1, CGK, HADH, SLC16A1, HNF4A and UCP2) have been identified to date in patients with congenital forms of hyperinsulinism (CHI). The most severe forms of $\mathrm{CHI}$ are due to mutations in $A B C C 8$ and KCJN11, which encode the two components of pancreatic $\beta$-cell ATP-sensitive potassium channel. Recent advancement in understanding the genetic aetiology, histological characterisation into focal and diffuse variety combined with improved imaging (such as fluorine 18 L-3, 4-dihydroxyphenylalanine positron emission tomography 18F-DOPA-PET scanning) and laparoscopic surgical techniques have greatly improved management. In adults, $\mathrm{HH}$ can be due to an insulinoma, pancreatogenous hypoglycaemic syndrome, post gastric-bypass surgery for morbid obesity as well as to mutations in insulin receptor gene. This review provides an overview of the molecular basis of $\mathrm{CHI}$ and outlines the clinical presentation, diagnostic criteria, and management of these patients.

Key words: Hyperinsulinism, hypoglycaemia in infancy, congenital hyperinsulinism, hyperinsulinaemic hypoglycaemia
\end{abstract}

Conflict of interest: None declared

Received: 24.08 .2012

Accepted: 13.09 .2012

\section{Introduction}

Hyperinsulinaemic hypoglycaemia $(\mathrm{HH})$ represents a group of clinically, genetically, and morphologically heterogeneous disorders characterized by dysregulation of insulin secretion by pancreatic $\beta$-cells (1). It is the commonest cause of both transient and persistent states of hypoglycaemia posing significant risk of permanent brain damage $(2,3,4)$. Insulin secretion from $\beta$-cells is precisely regulated by various mechanisms to maintain blood glucose values within the normal range (fasting blood glucose levels of $3.5-5.5 \mathrm{mmol} / \mathrm{L}$ ). $\mathrm{HH}-$ unregulated insulin secretion drives glucose into insulin-sensitive tissues (skeletal muscle, liver and adipose tissue) and prevents the generation of alternative energy substrates (such as lactate and ketone bodies due to inhibition of glycogenolysis, gluconeogenesis, lipolysis and ketogenesis) thereby depriving the brain of glucose and ketone bodies. It is this metabolic milieu that results in hypoglycaemic brain injury (2).

Clinically, $\mathrm{HH}$ can result in apneas, seizures, developmental delay, and learning disability (4). Hence, early identification and meticulous management of these patients is fundamental in preventing a neurological insult. $\mathrm{HH}$ can either be congenital hyperinsulinism $(\mathrm{CHI})$ or secondary to certain risk factors like birth asphyxia, intra-uterine growth retardation (5), Rh isoimmunisation (6) and maternal diabetes mellitus or associated with various developmental syndromes like Beckwith-Wiedemann syndrome or metabolic conditions like congenital disorders of glycosylation (CDG syndromes) (7). In adults, an insulinoma accounts for most cases of $\mathrm{HH}$. Other causes include noninsulinoma pancreatogenous hypoglycaemia 
syndrome (NIPHS), post gastric bypass surgery for morbid obesity and mutations in insulin receptor gene, which typically present with postprandial $\mathrm{HH}$. The incidence of $\mathrm{CHI}$ can vary between 1 in 40 000-50 000 in the general population to 1 in 2500 in certain communities with high rates of consanguinity (8). The clinical presentation can be varied ranging from completely asymptomatic, pharmacologically responsive mild disease to severe disease unresponsive to medication needing surgical intervention (9).

$\mathrm{CHI}$ are caused by genetic defects in key genes regulating insulin secretion. The genetic basis of $\mathrm{CHI}$ involves mutations in eight key genes (ABCC8, KCNJ11, GLUD1, GCK, HADH, SLC16A1, HNF4A and UCP2) $(10,11,12,13,14,15,16,17)$ identified so far, which regulate insulin secretion from the $\beta$-cells. The most severe forms are due to recessive inactivating mutations in $A B C C 8$ and KCJN11, which encode the two components of pancreatic $\beta$-cell ATP-sensitive potassium channel lencoding for the two proteins sulfonylurea receptor 1 (SUR1) and inward-rectifying potassium channel pore-forming (KIR6.2) of the pancreatic $\beta$-cell K $K_{\text {ATP }}$ channel, respectively]. Recessive forms of $\mathrm{CHI}$, due to mutations in the short chain hydroxyl-acyl-CoA dehydrogenase $(H A D H)$ are known to be rare (18). Dominant forms of $\mathrm{CHI}$ include activating mutations in encoding glutamate dehydrogenase (GLUD1), encoding glucokinase (GCK), encoding hepatocyte nuclear factor $4 a$ (HNF4A) and encoding monocarboxylate transporter1 (SLC16A1) $(12,15,16)$

Histological classification includes three major subgroups: diffuse, focal, and atypical, with the diffuse form inherited as autosomal recessive or dominant manner and the focal form being sporadic in inheritance. Pharmacologically unresponsive diffuse $\mathrm{CHI}$ may require a near-total pancreatectomy (with lifelong supplementation of pancreatic exocrine function and risk of developing diabetes mellitus), whereas the focal form requires a focal lesionectomy [with advanced preoperative fluorine 18 L-3, 4-dihydroxyphenylalanine positron emission tomography / computed tomography (18F-DOPA-PET/CT) imaging aiding resection of the focal lesion] thereby curing the patient from the hypoglycaemia. In patients with atypical disease, the histological abnormalities may be diffuse with the coexistence of normal and abnormal islets (19).

This review provides an overview of the clinical presentation, molecular basis, diagnostic tools, and management of $\mathrm{HH}$ with an emphasis on $\mathrm{CHI}$

\section{Clinical Presentation:}

$\mathrm{HH}$ is most commonly diagnosed in the newborn period however, milder cases may be diagnosed either during infancy or childhood (2). Clinical symptoms are most severe in the newborn period. The infant may present with apnea, seizures and unresponsiveness, or the symptoms may be less severe and non-specific (poor feeding, irritability and lethargy).
Newborns with $\mathrm{CHI}$ may be macrosomic due to hyperinsulinaemia in fetal life, particularly those who carry mutations in HNF4A (15). Some patients have hypertrophic cardiomyopathy and hepatomegaly probably reflecting fetal hyperinsulinaemia (20). HH may be associated with well-defined developmental syndromes (see reference table), the most common being Beckwith-Wiedemann syndrome. This is characterized by transient $\mathrm{HI}$ and pathognomonic physical signs which include exomphalos, hemihypertrophy, macroglossia, and transverse creases of the ear lobes (21).

Symptoms of hypoglycaemia can either be seen during fasting, or after a protein-rich meal challenge or exercise. Some patients demonstrate marked sensitivity to dietary protein (especially leucine) (22). Patients with exercise-induced $\mathrm{HH}$ typically present with symptoms of hypoglycaemia within the 30-45 minutes following a period of intensive anaerobic exercise (23). The hypoglycaemia is often refractory to frequent enteral feeds, and intravenous glucose infusion rates in excess of $15-20 \mathrm{mg} / \mathrm{kg} / \mathrm{min}$ are required to maintain a normoglycaemic state $(24,25)$. Neonates usually require central venous access for delivering high concentrations of intravenous glucose.

Adult-onset $\mathrm{HH}$ is usually caused by an insulinoma. The mean age at presentation is around 45 years; however, patients with insulinoma associated with type 1 multiple endocrine neoplasia usually present at younger ages. These patients usually develop hypoglycaemia symptoms after a fast but rarely have them postprandially. Patients with other conditions such as NIPHS, those who underwent gastric bypass surgery for severe obesity, and those with mutations in the insulin-receptor gene can also have postprandial hypoglycaemia $(26,27,28,29)$.

\section{Diagnosis of $\mathrm{HH}$ :}

Early recognition of $\mathrm{HH}$ is vital in preventing neuroglycopaenic brain injury. The diagnosis of $\mathrm{HH}$ is based on clinical presentation and on detection of its biochemical markers at the time of hypoglycaemia. Plasma insulin levels may not be dramatically elevated in $\mathrm{HH}$; rather, there is inadequate suppression of insulin at low blood glucose concentrations (2). Insulin release is pulsatile and measurement of C-peptide might be more helpful in some patients where the diagnosis is in doubt.

The diagnosis is most frequently based on evidence of excessive insulin action. The characteristic metabolic profile is hypoketonaemic, hypofattyacidaemic hypoglycaemia arising from the anabolic effects of insulin. A high glucose requirement ( $>8$ $\mathrm{mg} / \mathrm{kg} \mathrm{min}$, normal range $4-6 \mathrm{mg} / \mathrm{kg} \mathrm{min}$ ) to maintain normoglycaemia is a strong indicative measure of a defect in regulation of basal insulin secretion. In difficult to diagnose cases, supportive evidence can be provided by decreased serum levels of insulin-like growth factor-binding protein 1 (IGFBP-1) (as insulin suppresses the transcription of IGFBP-1 gene), a positive glycemic response to intramuscular/ intravenous glucagon at the 
time of hypoglycaemia (a clear increment in blood glucose of $>1.5 \mathrm{mmol} / \mathrm{L}$ despite severe hypoglycaemia), and a positive glycemic response to octreotide $(30,31)$.

Additional tests for specific forms of $\mathrm{CHI}$ include measuring the plasma ammonia level (12), performing a leucine provocation test $(\mathrm{GDH}-H)$, assessment of the plasma acylcarnitine profile (elevated 3-hydroxybutyryl-carnitine) and urine organic acids (3hydroxyglutarate in urine; $\mathrm{HADH}-\mathrm{CHI}$ ) (14). Performing an exercise provocation test and/or a pyruvate load test (SLC16A1CHI) may also be helpful (23).

In adults with $\mathrm{HH}$, a 72-h fast will detect $99 \%$ of insulinoma, which is the most common cause of $\mathrm{HH}$ in adults (32). Patients with postprandial $\mathrm{HH}$ do not exhibit symptoms after fasting tests, but hypoglycaemia can be detected by an oral glucose tolerance test (OGTT) or by a mixed-meal provocation test. No consensus exists on the best method with which to investigate postprandial HH. The OGTT, in particular, is often followed by a physiological dip in blood glucose level, which might lead to misdiagnosis. However, one can distinguish between pathological postprandial $\mathrm{HH}$ and 'reactive' hypoglycaemia by looking for corresponding biochemical evidence of endogenous hyperinsulinaemia and symptoms of neuroglycopenia during a hypoglycaemic episode. Elevated plasma insulin levels with undetectable C-peptide levels indicate exogenous insulin administration. Measurement of sulfonylureas in plasma and urine is recommended in all patients in whom the cause of $\mathrm{HH}$ is unclear, to rule out factitious hypoglycaemia due to administration of sulfonylureas.

\section{Aetiology of $\mathrm{HH}$}

\section{(1) Transient $\mathrm{HH}$}

When $\mathrm{HH}$ resolves spontaneously within a few days or a few weeks, a diagnosis of transient $\mathrm{HH}$ is made. Maternal diabetes mellitus (gestational or insulin-dependent), intra-uterine growth restriction, perinatal asphyxia, erythroblastosis fetalis, maternal administration of drugs such as sulphonylureas, and intravenous glucose infusions during labour tend to cause a transient form of $\mathrm{HH}$. There have been case reports of transient $\mathrm{HH}$ which were not associated with any of the above risk factors (33). Transient $\mathrm{HH}$ can be protracted in some patients with intrauterine growth restriction and asphyxia, requiring treatment with diazoxide (34). The underlying mechanism for transient $\mathrm{HH}$ remains unclear.

Molecular mechanisms of congenital forms of $\mathrm{HH}$ : The role of pancreatic $\beta$-cell function $\mathrm{K}_{\text {ATP }}$ channels in regulating insulin secretion

$K_{\text {ATP }}$ channels in pancreatic $\beta$-cells were first described to play an important role in insulin secretion over 20 years ago (35). They regulate the flux of $\mathrm{K}$ ions across cell membranes and thereby link cell metabolism to electrical activity. Glucose phosphorylation by GCK is the rate-limiting step that controls glucose-regulated insulin secretion. Further metabolism of glucose-6-phosphate via glycolysis generates ATP causing an increase in the intracellular phosphate potential (ATP/ADP ratio), which inhibits the activity of an ATP-sensitive $\mathrm{K}^{+}$channel leading to closure of the KATP channels resulting in membrane depolarization. This subsequently activates voltage-dependent calcium channels leading to an influx of Ca which in turn triggers the secretory granule to release insulin $(36,37,38,39)$.

The $\mathrm{K}_{\text {ATP }}$ channel is a hetero-octameric complex composed of four Kir6.2 subunits and four high-affinity SUR1 subunits (39). This channel has a role in linking glucose metabolism in the $\beta$-cell to insulin secretion. Glucose metabolism in $\beta$-cells raises the intracytosolic ATP/ADP ratio which inhibits the plasma membrane SUR1, thus closing the K ATP channel. This closure leads to cell membrane depolarization, $\mathrm{Ca}^{2}+$ influx via the voltage-gated $\mathrm{Ca}$ channels and release of insulin from storage granules (Figure 1).

\section{(2) Congenital Hyperinsulinism (CHI):}

Congenital hyperinsulinism is a group of genetic disorders comprising abnormalities in key genes involved in regulating insulin secretion. Only 50\% of monogenic forms of $\mathrm{CHI}$ have been identified to date. As shown in Table 1, these are classified as:

(a) Channelopathies

Pancreatic $\beta$-cell $K_{\text {ATP }}$ channel defects:

The most common and most severe form of $\mathrm{CH}$ results from recessive inactivating mutations in ABCC8 and KCNJ11 genes $(10,11)$. Loss-of-function mutations in these genes deregulate the precise mechanism by which glucose metabolism controls insulin secretion. The $\beta$-cell plasma membrane is constantly depolarized, causing $\mathrm{Ca}^{2+}$ influx and insulin secretion. The molecular basis of recessive inactivating ABCC8 and KCNJ11 mutations involves multiple defects in $\mathrm{K}_{\text {ATP }}$ channel biogenesis and turnover, in channel trafficking from the ER and Golgi apparatus to the plasma membrane, and in alterations of channels in response to both nucleotide regulation and open state frequency $(40,41,42,43)$.

As diazoxide is a $K_{\text {ATP }}$ channel agonist, the patients are usually diazoxide-unresponsive when the defect in ABCC8 or KCNJ11 abolishes the function of this channel. Dominant inactivating mutations of $A B C C 8$ and $K C N J 11$ usually cause milder forms of $\mathrm{CH}$ lalthough recently, medically unresponsive forms have been reported (44).

\section{Histological Subtypes of $\mathrm{HH}$ :}

Defects in K ATP channel lead to two clinically indistinguishable histopathological subtypes of $\mathrm{HH}$ - focal and diffuse. Focal $\mathrm{HH}$ is sporadic, while diffuse $\mathrm{HH}$ is autosomal recessively inherited or more rarely dominantly inherited. In diffuse $\mathrm{HH}, \beta$-cells throughout the pancreas are functionally abnormal and have characteristic enlarged nuclei in about $2 \%$ $5 \%$ of cells. Focal $\mathrm{HI}$ lesions are usually $<10 \mathrm{~mm}$ in diameter and are characterized by the presence of a confluent proliferation of 
islet-cell clusters (focal adenomatosis) (45). The abnormal or enlarged islet cell nuclei are often observed within the lesion but are not seen outside of the focal lesion where the islets exhibit small nuclei and less cytoplasm, with evidence of low proinsulin synthesis. Intraoperative frozen sections are essential, not only to confirm the diagnosis based on imaging but also to determine whether the suspected area effectively corresponds to a focal lesion and is completely resected.

In GCK-HI, descriptions of islet cell morphology vary, with normal-appearing islets in some cases and enlarged islet size in others. Histological studies have described diffuse islet cell "hyperplasia" in Beckwith-Wiedemann syndrome. Recently, a new histological form of $\mathrm{HH}$ has been described that is characterized by a morphological mosaicism. The abnormal hyperfunctional islets of this form are most often confined to a few adjacent lobules with possible cure by limited pancreatectomy (46).

\section{Focal}

Focal forms can either involve a small area (approximately 2.5 to $10 \mathrm{~mm}$ in diameter) of the pancreas or rarely very large areas. The focal lesions are made of large endocrine cells which have a large cytoplasm and nuclei that are 3-5 times the size of nearby acinar nuclei. The area of abnormal pancreatic development is multilobular and can have satellites in the nearby pancreatic tissue that necessitate intraoperative margins analysis to ensure complete excision and avoid recurrence. The focal lesions can sometimes be deeply embedded within the pancreatic tissue. Focal disease is always sporadic and has a distinctive genetic aetiology involving two independent events inheritance of a paternal mutation in $A B C C 8$ or $\mathrm{KCNJ} 11$ and somatic loss of the maternal $11 p$ allele (11p15.1 to 11p15.5) involving the $A B C C 8$ and $K C N J 11$ region within the focal lesion (47). The maternal allele loss unmasks the paternally inherited K ATP channel mutation in addition to an imbalance in the imprinted genes in this region (maternally expressed tumour

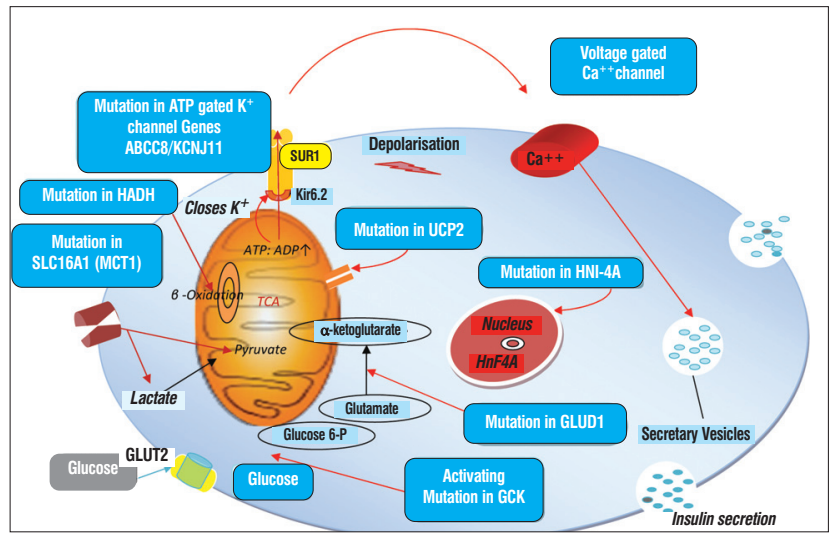

Figure 1. Schematic representation of the known causes of $\mathrm{HH}$ in the pancreatic $\beta$-cell suppressor genes $\mathrm{H} 19$ and CDKN1C, and the paternally expressed growth factor IGF2). An imbalance of the 11p15 region leads to increased proliferation of $\beta$-cells evolving into a focal adenomatous hyperplasia.

\section{Diffuse}

The diffuse form affects the whole of pancreas with variable involvement of the islets. The islet pattern is preserved, but it contains very active $\beta$-cells with very abundant cytoplasm and highly abnormal nuclei 3-4 times larger than normal size. The most common causes of diffuse $\mathrm{CHI}$ are the recessive and dominant mutations in $A B C C 8$ and $\operatorname{KCNJ11}(10,11)$. Neither clinical nor biological data can be used to differentiate the focal from the diffuse forms. However, the recently introduced noninvasive imaging using PET with 18F-DOPA is valuable in distinguishing these two forms $(48,49)$.

\section{Atypical}

Atypical forms remain poorly defined. The pattern of pancreatic involvement may be of the diffuse type but may be confined to one large area of the pancreas. The genetic basis of these atypical forms is yet to be clearly elucidated but some are explained by chromosomal mosaicism (50). A new form of $\mathrm{HI}$ that is characterized by a morphological mosaicism and a particular histology of limited islet nuclear enlargement (LINE) has been reported (46). The abnormal hyperfunctional islets of this form are most often confined to a few adjacent lobules. Over a 25-year period, 217 cases of operated persistent HI were reviewed, of which 16 cases $(7.4 \%)$ did not fit with the usual types. They displayed peculiar pancreatic morphologies and had a distinct clinical presentation, with normal birth weight in the majority of the cases, a late onset of $\mathrm{HH}$ and a relative sensitivity

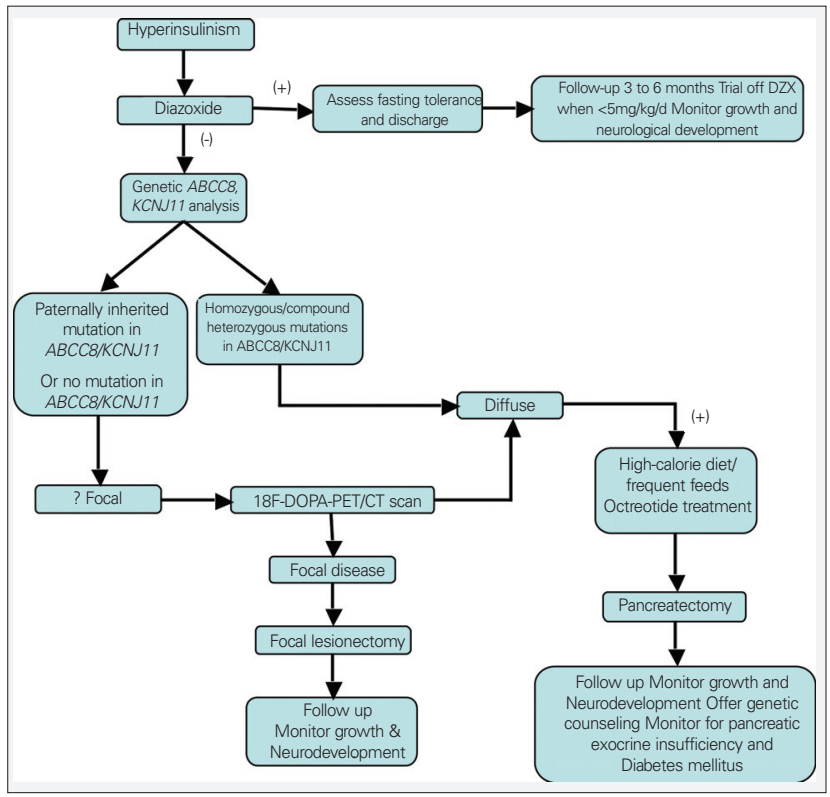

Figure 2. Outline of suggested management pathway 
to diazoxide. Furthermore, when genetic analyses were performed in these infants $(n=13)$, genomic mutations of ABCC8, KCNJ11, and GCK were ruled out, and no similar peculiar pathologies were found in cases with similar mutations. Intraoperative recognition and diagnosis of this particular form of $\mathrm{HI}$ can often be cured by a limited pancreatectomy (46).

\section{(b) Enzyme Defects}

I.Hyperinsulinism-Hyperammonaemia Syndrome (HI/HA):

$\mathrm{HI} / \mathrm{HA}$ syndrome, the second most common form of $\mathrm{CHI}$, is caused by activating mutations in the GLUD1 gene, which encodes for the intramitochondrial enzyme glutamate dehydrogenase (GDH) $(12,51,52,53,54,55,56)$. GDH activity is regulated by allosteric inhibitors (GTP) and activators (ADP and leucine). Mutations in GLUD1 lead to a gain of enzyme function by reducing its sensitivity to allosteric inhibition by high-energy phosphates such as GTP and ATP and allowing activation by the amino acid leucine.

$\mathrm{GDH}$ catalyzes the oxidative deamination of glutamate to $\alpha$ ketoglutarate and ammonia using NAD+ and/or NADP+ as cofactors and is widely distributed at high levels in the pancreas, liver, brain, kidney, heart, and lungs. In pancreatic $\beta$-cells, $\alpha$ ketoglutarate enters the Krebs cycle and increases the ATP/ADP ratio, thereby triggering the insulin release through inhibition of $\mathrm{K}_{\text {ATP }}$ channels. Increased GDH activity in liver may lead to HA because of excessive ammonia production and impaired urea cycle activity although this is not confirmed. Some recent animal studies suggest the role of renal ammoniagenesis due to activation of $\mathrm{GDH}$ as a source of $\mathrm{HA}$ in these patients (57). Sporadic (80\%) and dominantly inherited (20\%) mutations have been reported in the GTP-inhibitory allosteric binding site or in an antenna region of the enzyme.

Affected children have recurrent postprandial hypoglycaemia following protein-rich meals together with persistently elevated plasma ammonia. These patients do not typically present with hypoglycaemia at birth and frequently remain undiagnosed until several months of age and may present with seizures. Plasma ammonia levels are typically 2-5 times the upper limit of normal and stable with fasting and protein meals. There are patients described with $\mathrm{HI} / \mathrm{HA}$ syndrome with persistently normal serum ammonia. HA is usually asymptomatic and does not warrant

Table 1. Genetic classification of congenital hyperinsulinism

\begin{tabular}{|c|c|c|c|c|c|c|}
\hline Gene & Locus & Genetic form & Mechanism & Inheritance & Clinical features & Treatment \\
\hline АВСС 8 & $11 p 15.1$ & $\mathrm{~K}_{\mathrm{ATP}}-\mathrm{HH}$ & Defect in $\mathrm{K}_{\text {ATP }}$ channel & AR- Diffuse & Severe & Unresponsive \\
\hline KCJN11 & & & $\begin{array}{l}\text { biogenesis, turnover, } \\
\text { trafficking and nucleotide } \\
\text { regulation }\end{array}$ & $\begin{array}{l}\text { Focal - paternal } \\
\text { mutation* sporadic }\end{array}$ & hypoglycaemia & $\begin{array}{l}\text { to diazoxide - feeds } \\
\text { and surgery remain } \\
\text { mainstay of treatment }\end{array}$ \\
\hline АВСС8 & $11 \mathrm{p} 15.1$ & Dominant & Defect in $\mathrm{K}_{\text {ATP }}$ channel & & & \\
\hline KCJN11 & & $\mathrm{K}_{\mathrm{ATP}}-\mathrm{HH}$ & $\begin{array}{l}\text { biogenesis, turnover, } \\
\text { trafficking and nucleotide } \\
\text { regulation }\end{array}$ & $A D$ & $\begin{array}{l}\text { The less severe } \\
\text { form responds to } \\
\text { diazoxide }\end{array}$ & Diazoxide \\
\hline GLUD1 & $10 \mathrm{q} 23.3$ & $\mathrm{HI} / \mathrm{HA}$ & $\begin{array}{l}\text { High basal GDH activity } \\
\text { and loss of GTP suppressor } \\
\text { action on GDH }\end{array}$ & AD/DN & $\begin{array}{l}\text { Less severe form; } \\
\text { fasting \& PPHH; } \\
\text { High ammonia; } \\
\text { Protein-sensitive }\end{array}$ & Diazoxide \\
\hline GCK & $7 p 15-13$ & GCK- HH & $\begin{array}{l}\text { High glucose affinity by } \\
\text { glucokinase }\end{array}$ & $A D / D N$ & $\begin{array}{l}\text { Variable phenotype; } \\
\text { MODY2 later life }\end{array}$ & $\begin{array}{l}\text { Ranges from diazoxide } \\
\text { responsive form to } \\
\text { unresponsive form } \\
\text { needing surgery }\end{array}$ \\
\hline $\mathrm{HADH}$ & $4 q 22-26$ & HADH-HH & Unknown & $A R$ & $\begin{array}{l}\text { Mild to severe } \\
\text { forms ** }\end{array}$ & Diazoxide \\
\hline SLC16A1 & 1p13.2p12 & (EIHI) MCT1 & $\begin{array}{l}\text { Increased expression of } \\
\text { MCT1 on ß-cells }\end{array}$ & $A D$ & $\begin{array}{l}\text { Anaerobic exercise- } \\
\text { sensitive hypoglycaemia }\end{array}$ & $\begin{array}{l}\text { May or may not } \\
\text { respond to diazoxide }\end{array}$ \\
\hline HNF4A & $20 q 1213.1$ & $H N F 4 \alpha$ & Unknown & $\mathrm{AD} / \mathrm{DN}$ & $\begin{array}{l}\text { Dual phenotype: } \mathrm{HH} \text { in } \\
\text { neonate MODY1 later life }\end{array}$ & Diazoxide \\
\hline UCP2 & $11 q 13.4$ & UCP2-HI & Unknown & $A D$ & Mild HH & Diazoxide \\
\hline
\end{tabular}

*Paternal inherited SUR1 or KIR6.2 mutation+ loss of 11 p15 maternal allele in pancreatic lesion; ** abnormal carnitine $\mathrm{HH}$ : hyperinsulinaemic hypoglycaemia, HA: hyperammonaemia, HI: hyperinsulinism, HADH: hydroxyacyl coenzyme A dehydrogenase, GDH: glutamate dehydrogenase, MCT1: monocarboxylate transporter 1, GCK: glucokinase, MODY1: maturity-onset diabetes of the young type 1 
treatment. The hypoglycaemia in patients with $\mathrm{HI} / \mathrm{HA}$ syndrome is usually diazoxide-responsive (58).

\section{Hydroxyacyl Coenzyme A Dehydrogenase and}

Hyperinsulinism (HADH and $\mathrm{HI}$ )

Mutations in $H A D H$, the gene encoding the mitochondrial enzyme L-3 HADH, are a rare cause of recessively inherited $\mathrm{HH}$. $H A D H$ catalyzes the penultimate step in the $\beta$-oxidation of fatty acids (the nicotinamide adenine dinucleotide (NAD+)-dependent dehydrogenation of $\mathrm{L}-3 \mathrm{HADH}$ to the corresponding 3-ketoacylcoenzyme A.

$H A D H$ is highly expressed in pancreatic $\beta$-cells, suggesting it has an important role in insulin secretion. $H A D H$ expression is regulated by transcription factors (such Foxa2) that are crucial for proper $\beta$-cell differentiation and function. $\beta$-cellspecific Foxa2 knockout mice show a 3-fold down-regulation of $H A D H$ and severe HH (59). Suppression of HADH activity using small interfering RNA caused a significant increase in basal insulin secretion compared with untreated cells. The addition of diazoxide did not alter the enhanced basal insulin secretion caused by $H A D H$ suppression, indicating that $H A D H$ functions through $\mathrm{K}_{\text {ATP-independent }}$ pathway to regulate insulin secretion $(60,61)$.

The precise mechanism behind dysregulated insulin secretion in patients with $H A D H$ mutations is not well

Table 2. Causes of hyperinsulinaemic hypoglycaemia (HH)

Secondary causes (generally transient)

Maternal diabetes mellitus (gestational and insulin-dependent)

Intrauterine growth restriction (IUGR)

Perinatal asphyxia

Rhesus isoimmunisation

Congenital hyperinsulinism (most common gene mutations identified)

ABCC8

KCNJ11

GLUD1

GCK

$H A D H$

HNF4A

SLC16A1

UCP2

Metabolic conditions

Congenital disorders of glycosylation (CDG), Type 1a/b/d

Tyrosinaemia type I

Syndromic associations

Beckwith-Wiedemann

Kabuki

Trisomy 13

Mosaic Turner

Soto

Usher

Timothy

Costello

Central hypoventilation syndrome

Leprechaunism (insulin resistance syndrome)

Miscellaneous causes

Insulinoma (sporadic or associated with MEN Type 1)

Insulin gene receptor mutations

Insulin autoimmune syndrome

Postprandial $\mathrm{HH}$ after gastric bypass surgery

Dumping syndrome

Drug-induced (sulfonylureas, glinides, biguanides, beta-blockers, cibenzoline, quinine)

Non-islet cell tumor hypoglycaemia (NICTH)

Noninsulinoma pancreatogenous hypoglycaemia syndrome (NIPHS) 
understood but might involve an interaction between $H A D H$ and $\mathrm{GDH}$ as protein sensitivity, which is a feature of gain-of-function mutations in $\mathrm{GDH}$ and which has also been demonstrated in patients with $H A D H$ mutations. This finding has been confirmed in $H A D H$ knockout mice (62). Direct protein-protein interactions between $\mathrm{GDH}$ and $H A D H$ have been demonstrated in control human lymphoblasts, which are lost in patients with $H A D H$ mutations causing leucine-induced $\mathrm{HH}$ (63). It is likely that $H A D H$ mutations cause leucine sensitivity and dysregulated insulin secretion via a novel pathway not involving GTP regulation of $\mathrm{GDH}$.

The clinical phenotype of $H A D H$ mutations varies from severe neonatal $\mathrm{HH}$ to mild late-onset $\mathrm{HH}$. Abnormal acylcarnitine metabolites (raised plasma hydroxybutyrylcarnitine and urinary 3-hydroxyglutarate levels) might give a clue to the diagnosis in some patients (14). In contrast to other defects in fatty acid oxidation, children with $H A D H$ mutation have no signs of hepatic dysfunction, cardiomyopathy, or effects on skeletal muscle. All patients reported so far have responded to diazoxide. Genetic analysis of $H A D H$ gene is recommended in patients with diazoxide-responsive $\mathrm{HH}$ from consanguineous families, who are negative for mutations in the K KTP channels (64).

\section{Exercise-Induced Hyperinsulinism (EIHI) (SLC16A1)}

$\mathrm{EIHI}$ is a dominantly inherited condition due to mutations in the promoter region of SLC16A1 gene, leading to increased expression of the plasma membrane monocarboxylate transporter 1 (MCT1) in the $\beta$-cell (16). Under normal conditions, expression of MCT1 in the pancreatic $\beta$-cell is very low, which minimizes the effects of pyruvate and lactate on insulin secretion. miR-29a and miR-29b (microRNAs) have been shown to contribute to pancreatic $\beta$-cell-specific silencing of MCT1 (65).

The increased level of MCT1 due to promoter-activating mutations in SLC16A1 allows the circulating pyruvate/lactate to enter $\beta$-cells, where it acts as a substrate for mitochondrial oxidation leading to an increased cytosolic ATP/ADP ratio. This triggers insulin release despite the absence of elevated blood glucose levels, resulting in hypoglycaemia. Affected patients become hypoglycaemic typically 30 to 45 minutes after a period of intensive anaerobic exercise due to accumulation of lactate and pyruvate (16).

\section{Glucokinase- Induced Hyperinsulinism (HI)}

Activating glucokinase (GCK) mutations are a rare cause of medically responsive $\mathrm{CHI}$ (66). Glucose phosphorylation by GCK is the rate-limiting step that controls glucose-regulated insulin secretion. Activating mutations lead to a left shift of the glucose dependency curve resulting in lower threshold for glucosestimulated insulin release. Glucokinase has a similar role as glucose sensor in other body cells such as entero-endocrine cells, hepatocytes, and hypothalamic neurons (67).

The activating GCK mutations are inherited in an autosomal dominant manner with a highly variable phenotype even within families with the same GCK mutation. GCK-CHI can either present during the neonatal period or at a much later stage, even as late as adulthood. The majority of GCK-CHI patients are diazoxide-responsive, but occasional severe phenotypes require more intensive management including octreotide and subtotal pancreatectomy (68). Diazoxide-responsive $\mathrm{CHI}$ patients, negative for $K_{\text {ATP }}$ mutations, should be considered for GCK genetic testing. Although GCK-CHI is known to be of low prevalence, if an activating GCK mutation is identified in the family, other members should be screened to detect asymptomatic or mild symptomatic $\mathrm{CHI}$ (69).

\section{$V$. Mutations in the Mitochondrial Uncoupling Protein 2}

\section{(UCP2) Gene and Hyperinsulinaemic Hypoglycaemia (HH)}

UCP2 induces a regulated leak of protons across the inner mitochondrial membrane and uncouples mitochondrial oxidative metabolism from ATP synthesis. Consequently, cell ATP content decreases, as well as insulin secretion. UCP2 over-expression in rat-isolated pancreatic islet cells decreases the ATP content and inhibits glucose-stimulated insulin secretion (17). Conversely, UCP2 knockout mice exhibit HH. UCP2 loss-of-function mutations were recently reported in two unrelated children with neonatal-onset congenital $\mathrm{HH}$ and hypoglycaemia which were diazoxide-responsive (17).

\section{(c) Transcription Factor Defects \\ HNF4A and $H H$}

Mutations in HNF4A are one of the less common causes of $\mathrm{HH}$, which can either be transient or persistent. HNF4A gene encodes for the transcription factor hepatocyte nuclear factor 4 alpha (HNF-4 $\alpha$ ), which belongs to the nuclear hormone receptor superfamily and is required in the pancreatic $\beta$-cell for regulation of the pathway of insulin secretion. Lossof-function HNF4A mutations cause maturity-onset diabetes of the young type 1 (MODY1), which is characterized by progressive $\beta$-cell destruction and failure of glucose-induced insulin secretion $(70,71)$.

HNF- $4 \alpha$ binds to the promoters of $11 \%$ of the pancreatic islets genes, and it is quite likely that HNF $4 \alpha$ deficiency probably exhibits its phenotype via abnormal gene expression of one or more of these target genes. The possible mechanism behind $\mathrm{HH}$ in HNF4A mutations either might be reduction in expression of the $\mathrm{K}$ channel subunit Kir6.2 and/or reduction in the expression of nuclear receptor peroxisome proliferator-activated receptor $\alpha$ (PPAR $\alpha$ ). PPAR $\alpha$ shifts energy metabolism in cells towards fatty acid oxidation (FAO) in response to starvation. Isolated islets from PPAR $\alpha$ null mice were noticed to have a $44 \%$ reduction in FAO and enhanced glucose-induced insulin secretion $(72,73)$.

The clinical phenotype ranges from macrosomia to mild transient hypoglycaemia not requiring pharmacological treatment or to persistent $\mathrm{HH}$ treated with diazoxide for up to 8 years. Only a minority of HNF4A mutation carriers have been reported to develop $\mathrm{HH}$. Mutations may arise de novo, and 
parents of HNF4A-mutation children might not have diabetes. Hence, the absence of a history of diabetes in the parents should not preclude sequencing of the HNF4A gene (71).

(3) Postprandial forms of $\mathrm{HH}$

Inappropriate insulin secretion in response to a meal can lead to hypoglycaemia within a few hours of meal ingestion (postprandial $\mathrm{HH}$ ). In children, the most common cause of postprandial HH is 'dumping' syndrome seen in infants who have undergone Nissen's fundoplication (74). Precipitous emptying of hyperosmolar carbohydrate-containing solutions into the small bowel shifts fluid into the bowel lumen, which results in hypovolaemia, rapid glucose absorption, hyperglycaemia, and reactive hypoglycaemia. It has been noted that children with postprandial HH after Nissen's fundoplication have abnormally exaggerated secretion of glucagon-like peptide1 (GLP-1), which may contribute to the exaggerated insulin surge and resultant hypoglycaemia (75).

Patients with postprandial $\mathrm{HH}$ do not exhibit symptoms after fasting tests, but hypoglycaemia can be made apparent by an OGTT or by a mixed-meal provocation test. No consensus exists on the best method to investigate postprandial $\mathrm{HH}$. The OGTT, in particular, is often followed by a physiological dip in blood glucose level, which might lead to misdiagnosis. However, one can distinguish between pathological postprandial $\mathrm{HH}$ and 'reactive' hypoglycaemia by looking for corresponding biochemical evidence of endogenous hyperinsulinaemia and symptoms of neuroglycopenia during a hypoglycaemic episode (either spontaneous or following a provocation test). A decrease of $>6 \mathrm{mmol} / \mathrm{L}$ between peak and nadir glucose has been proposed as a diagnostic criterion for dumping syndrome (76).

Most other presentations of postprandial $\mathrm{HH}$ have been reported in adults. Postprandial $\mathrm{HH}$ has been described in patients with insulin autoimmune syndrome. NIPHS (77) has been described in patients who have undergone gastric bypass surgery for morbid obesity (78) and in carriers of mutations in the insulin-receptor gene (26).

\section{(4) Other Causes of HH (Table 2)}

The term Munchausen syndrome by proxy (MSP) describes a form of child abuse involving the mother's, a parent's, or another guardian's falsifying illness in a child. Diagnosis is difficult because caregivers are adept at deceiving medical and mental health professionals. Cases of chronic surreptitious administration of insulin or antidiabetic drugs such as sulfonamides to children and adults have been reported, with some being treated with pancreatectomy to control hypoglycaemia $(79,80)$.

Management (Figure 2):

\section{1) Immediate Management}

Prompt diagnosis with aggressive early intervention to prevent hypoglycaemia remains the mainstay of treatment required to avert irreversible brain damage $(4,81)$. Due to the hypoketonaemic, hypofattyacidaemic hypoglycaemia arising from the anabolic effects of insulin preventing the generation of alternative brain fuel, it is recommended that a higher threshold of blood glucose concentration be used to intervene and that this level is maintained (operational threshold for intervention in $\mathrm{HH}$ is $3.5 \mathrm{mmol} / \mathrm{L}$, below which will lead to neuroglycopenia) (82). This often requires the insertion of a central venous catheter to deliver concentrated solutions of glucose intravenously.

A combination of oral feeds with a glucose polymer (such as SOS, Maxijul or Polycal) and intravenous fluids can be used to meet the carbohydrate requirement in these infants. It is vital to determine the minimum glucose infusion rate required to maintain normoglycaemia both for diagnostic and management purposes (a rate of $>10 \mathrm{mg} / \mathrm{kg} / \mathrm{min}$ is a specific diagnostic marker for $\mathrm{HH}$ ) (2). Glucose requirement may exceed the glucose infusion tolerance needing a concomitant IV glucose infusion with enteral feeding. The severity of hypoglycaemia or the rate of glucose required to maintain normoglycaemia cannot accurately predict the form of hypoglycaemia: whether it is transient, genetic, focal, or diffuse.

\section{Emergency Drug Treatment:}

\section{Glucagon:}

Intramuscular glucagon (0.5-1 $\mathrm{mg}$ ) can be used in an emergency situation where venous access is difficult to obtain. Continuous subcutaneous or intravenous glucagon infusion can be initiated for refractory hypoglycaemia despite high glucose infusion rate during acute management. Glucagon can be administered alone or in combination with octreotide. Glucagon improves blood glucose concentration by immediate release of glycogen stores from the liver and stimulating gluconeogenesis, ketogenesis, and lipolysis (83). In high doses, glucagon can cause paradoxical insulin secretion, implying that infants receiving glucagon bolus should receive intravenous glucose infusion to prevent rebound hypoglycaemia. Glucagon has no role in long-term management of $\mathrm{HH}$ (84).

\section{2) Further management}

This involves assessing the response to different medical therapies (83). When there is no improvement in the first few days (transient $\mathrm{HI}$ e.g. gestational diabetes), specific treatment outlined for $\mathrm{HI}$ should be initiated. It is important to assess the response to each medication before moving onto the next step.

\section{Diazoxide:}

Diazoxide is the first-line drug for management of $\mathrm{HH}$. It acts by opening the $\mathrm{K}_{\text {ATP }}$ channels via binding to the intact SUR1 component, thereby preventing glucose-stimulated insulin secretion. Figure 1 shows the management cascade and outlines the medical therapies used. Fluid retention and hypertrichosis are the most common side effects of diazoxide. In newborns, it is used in conjunction with chlorothiazide, a diuretic, to overcome the adverse effects of fluid retention (83). In older children, hypertrichosis can sometimes be marked and 
distressing but will be reversible after its withdrawal (85). Diazoxide is effective in virtually all forms of $\mathrm{HH}$ except in those due to recessive (and some dominant) inactivating mutations in ABCC 8 and KCNJ11 and in patients with focal $\mathrm{CHI}$. Diazoxide responsiveness is determined by a) appropriate fasting tolerance for age; b) feed volume and frequency normal for age; c) normal blood sugar levels at the end of the fast. Octreotide must be tried before considering surgery in case of diazoxideunresponsiveness (86). In these patients, further investigations (genetic analysis or mutations in ABCC8/KCNJ11 and 18FDOPA-PET/CT scan) are essential to differentiate focal from diffuse disease as the surgical approaches are radically different.

\section{Somatostatin Analogue: Octreotide}

Octreotide is the second-line drug for $\mathrm{HH}$ and is given as 68 hourly by subcutaneous injections. The starting dose is 5$10 \mu \mathrm{g} / \mathrm{kg} /$ day and the dose can be increased according to response up to $15-40 \mu \mathrm{g} / \mathrm{kg} /$ day. Tachyphylaxis leads to a rapid decrease in the response to octreotide 24-48 hours after treatment initiation. Hence, response can be assessed only 2 days after the initiation of a new dose. The criteria for responsiveness to octreotide are the same as for diazoxide. The common side effects include vomiting and/or diarrhea and abdominal distension, which resolve spontaneously within a week of initiation. However, fatal necrotizing enterocolitis has also been reported in some neonates, which warrants careful monitoring of neonates on octreotide treatment (87). Gallbladder sludge or stones are rare long-term complications which necessitate serial ultrasound screening. Long-acting somatostatin analogues are being studied in different $\mathrm{HI}$ centers to investigate their effectiveness and their impact on the patients' quality of life $(88,89)$.

\section{Response to Medical Therapy:}

Spontaneous clinical recovery can occur in some patients relatively early (within several months) or later (several years). Most patients outgrow the dose of diazoxide and octreotide during childhood and can be assessed by controlled fast off these medications. Once they are on a very small dose, the treatment can be stopped to assess resolution of $\mathrm{HH}$. However, some patients require continuous adjustment of the dose due to increase in size as they grow. Recurrence of hypoglycaemia may occur if this adjustment is not made. Such patients may continue to require diazoxide or octreotide for decades (90).

\section{Diazoxide-Unresponsive $\mathrm{CHI}$ :}

The management of patients who are diazoxide unresponsive has radically changed in the last few years due to advances in molecular genetics, radiological imaging techniques and laparoscopic surgery. In diazoxide-unresponsive patients, it is essential to have rapid genetic analysis for mutations in ABCC8/KCNJ11 and/or 18F-DOPA-PET/CT scan to plan subsequent treatment (91). Patients with genetically confirmed diffuse disease do not require further imaging studies.
Mutations in ABCC8 and KCNJ11 allow identification of the majority of patients with diffuse disease (homozygous or compound heterozygous mutations in $A B C C 8$ and KCNJ11).

Patients with a paternally inherited mutation in $A B C C 8$ or KCNJ11 (or those with no mutations in these genes) potentially can have a focal disease and thus will require further imaging studies with 18F-DOPA-PET scan to differentiate focal from diffuse disease. In addition, it allows precise pre-operative localization of the focal lesion. Nearly $50 \%$ of diazoxideunresponsive patients have focal disease. 18F-DOPA-PET/CTscan localization and limited surgical removal leads to complete cure of the hypoglycaemia. In contrast, patients with diazoxideunresponsive diffuse disease may require a near-total pancreatectomy which will have lifelong implications (high risk of diabetes mellitus, pancreatic exocrine insufficiency) $(92,93)$.

\section{Fluorine 18 L-3, 4-Dihydroxyphenylalanine Positron}

\section{Emission Tomography (18F-DOPA-PET):}

This is a novel imaging technique which helps in the pre-operative localization of focal lesions (48). The principle of 18F-DOPA-PET scan is based on the tissue uptake of L-DOPA. Pancreatic islets are able to uptake L-DOPA and convert it to dopamine through DOPA decarboxylase, so that DOPA hyperfunctional activity can be traced. The uptake of the positron emitting tracer 18F-DOPA-PET is increased in ß-cells with a high rate of insulin synthesis and secretion compared to unaffected areas allowing visualization of the focal lesion. The sensitivity for detecting focal lesions varies between 88 and $94 \%$ with an accuracy of $100 \%$ (94). Therefore, this technique plays an important role in indicating and determining the type of surgery (partial pancreatectomy in case of a focal form or subtotal pancreatectomy for diffuse form) $(95,96,97,98,99)$.

\section{Surgical Management of $\mathrm{CHI}$}

The focal form of the disease requires a limited pancreatectomy, whereas diffuse disease will require a neartotal pancreatectomy (45). In the surgery for excision in patients with the focal form, per-operative histology will search for abnormal cells at the margin. Additional resections until margins are clear may need to be performed. The patient can be cured from the hypoglycaemia if the focal lesion is completely excised. Diffuse $\mathrm{HI}$ requires near-total pancreatectomy $195-98 \%$ of the pancreas) leaving just the small triangle of pancreatic tissue between the duodenum and the common bile duct. Disturbance in glucose homeostasis may persist $(50 \%)$ but is more manageable than before surgery. The use of laparoscopy represents a new approach to the diagnosis and management of infants with $\mathrm{CHI}$ (100). Near-total pancreatectomy is associated with a high incidence of diabetes mellitus and pancreatic exocrine insufficiency, hence reserved for those severe cases where all medical therapy has failed $(93,101)$.

Medical Management of Diazoxide-Unresponsive Diffuse 


\section{$\mathrm{CHI}$}

In patients who are unresponsive or partially responsive $\mathrm{HI}$, it is paramount to provide high amounts of glucose to maintain normoglycaemia. This can be achieved by frequent glucoseenriched oral feedings and frequent or continuous enteral feedings. The principle of this treatment is based on the fact that the hypoglycaemia in some patients gradually gets milder over time. Some infants with diazoxide-unresponsive diffuse disease may be managed with long-term subcutaneous octreotide injections in combination with frequent feedings (88). A gastrostomy is recommended in these patients to allow the delivery of frequent bolus and continuous overnight feeds. Successful treatment with long-acting octreotide has been reported in ten patients, with an average follow-up of 17 months. Ongoing studies on long-acting somatostatin analogues investigate their effectiveness and their impact on the patient's quality of life (102).

\section{Summary}

$\mathrm{HH}$ is an important cause of hypoglycaemia in childhood caused by unregulated insulin secretion by $\beta$-cells. Hence, early identification and meticulous management of these patients is vital to prevent neurological insult. Improved understanding of the genetic mechanisms leading to the $\mathrm{CHI}$ has begun to unfold the heterogeneity seen with this condition providing new insights into the mechanisms involved in insulin secretion. Recent advances in the fields of molecular genetics coupled with imaging techniques (18F-DOPA-PET scanning) and laparoscopic surgery have improved the clinical care of infants with $\mathrm{CHI}$.

\section{References}

1. de Lonlay P, Fournet JC, Touati G, Groos MS, Martin D, Sevin C Delagne $V$, Mayaud C, Chigot V, Sempoux C, Brusset MC, Laborde K, Bellane-Chantelot C, Vassault A, Rahier J, Junien C, Brunelle F, Nihoul-Fekete C, Saudubray JM, Robert JJ. Heterogeneity of persistent hyperinsulinaemic hypoglycaemia. A series of 175 cases. Eur J Pediatr 2002;161:37-48.

2. Aynsley-Green A, Hussain K, Hall J, Saudubray JM, NihoulFekete C, De Lonlay-Debeney P, Brunelle F, Otonkoski T, Thornton $P$, Lindley KJ. Practical management of hyperinsulinism in infancy. Arch Dis Child Fetal Neonatal Ed 2000;82:98-107.

3. Mercimek-Mahmutoglu S, Rami B, Feucht M, Herle M, Rittinger O, Stoeckler-Ipsiroglu S, Schober E. Long-term follow-up of patients with congenital hyperinsulinism in Austria. J Pediatr Endocrinol Metab 2008;21:523-532.

4. Menni F, de Lonlay P, Sevin C, Touati G, Peigne C, Barbier V, Nihoul-Fekete C, Saudubray JM, Robert JJ. Neurologic outcomes of 90 neonates and infants with persistent hyperinsulinemic hypoglycemia. Pediatrics 2001;107:476-479.

5. Collins JE, Leonard JV. Hyperinsulinism in asphyxiated and smallfor-dates infants with hypoglycaemia. Lancet 1984;2:311-313.

6. Brown G, Brown R, Hey E. Fetal hyperinsulinism in rhesus isoimmunization. Am J Obstet Gynecol 1978;131:682-686.
7. Sun L, Eklund EA, Chung WK, Wang $\mathrm{C}$, Cohen J, Freeze $\mathrm{HH}$. Congenital disorder of glycosylation id presenting with hyperinsulinemic hypoglycemia and islet cell hyperplasia. J Clin Endocrinol Metab 2005;90:4371-4375. Epub 2005 Apr 19

8. Arnoux JB, Verkarre V, Saint-Martin C, Montravers F, Brassier A, Valayannopoulos $\mathrm{V}$, Brunelle F, Fournet JC, Robert JJ, Aigrain $\mathrm{Y}$, Bellanne-Chantelot $\mathrm{C}$, de Lonlay P. Congenital hyperinsulinism: current trends in diagnosis and therapy. Orphanet $\mathrm{J}$ Rare Dis 2011:6:63.

9. Fekete CN, de Lonlay P, Jaubert F, Rahier J, Brunelle F, Saudubray $\mathrm{JM}$. The surgical management of congenital hyperinsulinemic hypoglycemia in infancy. J Pediatr Surg 2004;39:267-269.

10. Thomas PM, Cote GJ, Wohllk N, Haddad B, Mathew PM, Rabl W, Aguilar-Bryan L, Gagel RF, Bryan J. Mutations in the sulfonylurea receptor gene in familial persistent hyperinsulinemic hypoglycemia of infancy. Science 1995;268:426-429

11. Thomas $P, Y e Y$, Lightner $E$. Mutation of the pancreatic islet inward rectifier Kir6.2 also leads to familial persistent hyperinsulinemic hypoglycemia of infancy. Hum Mol Genet 1996;5:1809-1812.

12. Stanley CA, Lieu YK, Hsu BY, Burlina AB, Greenberg CR, Hopwood NJ, Perlman K, Rich BH, Zammarchi E, Poncz M. Hyperinsulinism and hyperammonemia in infants with regulatory mutations of the glutamate dehydrogenase gene. $\mathrm{N}$ Engl J Med 1998;338:1352-1357.

13. Glaser B, Kesavan P, Heyman M, Davis E, Cuesta A, Buchs A, Stanley CA, Thornton PS, Permutt MA, Matschinsky FM, Herold $\mathrm{KC}$. Familial hyperinsulinism caused by an activating glucokinase mutation. N Engl J Med 1998;338:226-230.

14. Clayton PT, Eaton S, Aynsley-Green A, Edginton M, Hussain K, Krywawych S, Datta V, Malingre HE, Berger R, van den Berg IE. Hyperinsulinism in short-chain L-3-hydroxyacyl-CoA dehydrogenase deficiency reveals the importance of betaoxidation in insulin secretion. J Clin Invest 2001;108:457-465.

15. Pearson ER, Boj SF, Steele AM, Barrett T, Stals K, Shield JP, Ellard S, Ferrer J, Hattersley AT. Macrosomia and hyperinsulinaemic hypoglycaemia in patients with heterozygous mutations in the HNF4A gene. PLoS Med 2007;4:118.

16. Otonkoski T, Jiao H, Kaminen-Ahola N, Tapia-Paez I, Ullah MS, Parton LE, Schuit F, Quintens R, Sipila I, Mayatepek E, Meissner T, Halestrap AP, Rutter GA, Kere J. Physical exercise-induced hypoglycemia caused by failed silencing of monocarboxylate transporter 1 in pancreatic beta cells. Am J Hum Genet 2007;81:467-474. Epub 2007 Jul 26

17. Gonzalez-Barroso MM, Giurgea I, Bouillaud F, Anedda A, Bellanne-Chantelot $C$, Hubert $L$, de Keyzer $Y$, de Lonlay $P_{\text {, }}$ Ricquier D. Mutations in UCP2 in congenital hyperinsulinism reveal a role for regulation of insulin secretion. PLOS One 2008;3:e3850. Epub 2008 Dec 9

18. Marquard J, Palladino AA, Stanley CA, Mayatepek E, Meissner T. Rare forms of congenital hyperinsulinism. Semin Pediatr Surg 2011;20:38-44.

19. Sempoux C, Capito C, Bellanne-Chantelot C, Verkarre V, de Lonlay P, Aigrain Y, Fekete C, Guiot Y, Rahier J. Morphological mosaicism of the pancreatic islets: a novel anatomopathological form of persistent hyperinsulinemic hypoglycemia of infancy. $J$ Clin Endocrinol Metab 2011;96:3785-3793. Epub 2011 Sep 28

20. Mehta A, Hussain K. Transient hyperinsulinism associated with macrosomia, hypertrophic obstructive cardiomyopathy, hepatomegaly, and nephromegaly. Arch Dis Child 2003;88:822-824. 
21. Munns CF, Batch JA. Hyperinsulinism and BeckwithWiedemann syndrome. Arch Dis Child Fetal Neonatal Ed 2001:84:67-69.

22. Hsu BY, Kelly A, Thornton PS, Greenberg CR, Dilling LA, Stanley CA. Protein-sensitive and fasting hypoglycemia in children with the hyperinsulinism/hyperammonemia syndrome. J Pediatr 2001;138:383-389.

23. Otonkoski T, Kaminen N, Ustinov J, Lapatto R, Meissner T, Mayatepek E, Kere J, Sipila I. Physical exercise-induced hyperinsulinemic hypoglycemia is an autosomal-dominant trait characterized by abnormal pyruvate-induced insulin release. Diabetes 2003;52:199-204.

24. Hussain K, Aynsley-Green A. Management of hyperinsulinism in infancy and childhood. Ann Med 2000;32:544-551.

25. Hussain K. Congenital hyperinsulinism. Semin Fetal Neonatal Med 2005;10:369-376.

26. Hojlund K, Hansen T, Lajer M, Henriksen JE, Levin K, Lindholm $\mathrm{J}$, Pedersen O, Beck-Nielsen $\mathrm{H}$. A novel syndrome of autosomaldominant hyperinsulinemic hypoglycemia linked to a mutation in the human insulin receptor gene. Diabetes 2004;53:1592-1598.

27. Khoo TK, Service FJ. Hyperinsulinemic hypoglycemia. Endocr Pract 2007;13:424-426

28. Service FJ. Recurrent hyperinsulinemic hypoglycemia caused by an insulin-secreting insulinoma. Nat Clin Pract Endocrinol Metab 2006;2:467-470; quiz following 470.

29. Service FJ, Natt N, Thompson GB, Grant CS, van Heerden JA, Andrews JC, Lorenz E, Terzic A, Lloyd RV. Noninsulinoma pancreatogenous hypoglycemia: a novel syndrome of hyperinsulinemic hypoglycemia in adults independent of mutations in Kir6.2 and SUR1 genes. J Clin Endocrinol Metab 1999;84:1582-1589.

30. Finegold DN, Stanley CA, Baker L. Glycemic response to glucagon during fasting hypoglycemia: an aid in the diagnosis of hyperinsulinism. J Pediatr 1980;96:257-259.

31. Levitt Katz LE, Satin-Smith MS, Collett-Solberg P, Thornton PS, Baker L, Stanley CA, Cohen P. Insulin-like growth factor binding protein-1 levels in the diagnosis of hypoglycemia caused by hyperinsulinism. J Pediatr 1997;131:193-199.

32. Grant CS. Insulinoma. Best Pract Res Clin Gastroenterol 2005;19:783-798.

33. Yap F, Hogler W, Vora A, Halliday R, Ambler G. Severe transient hyperinsulinaemic hypoglycaemia: two neonates without predisposing factors and a review of the literature. Eur J Pediatr 2004;163:38-41.

34. Fafoula O, Alkhayyat H, Hussain K. Prolonged hyperinsulinaemic hypoglycaemia in newborns with intrauterine growth retardation. Arch Dis Child Fetal Neonatal Ed 2006;91:467.

35. Ashcroft FM, Harrison DE, Ashcroft SJ. Glucose induces closure of single potassium channels in isolated rat pancreatic betacells. Nature 1984;312:446-448.

36. Shyng S, Ferrigni T, Nichols CG. Regulation of KATP channel activity by diazoxide and MgADP. Distinct functions of the two nucleotide binding folds of the sulfonylurea receptor. J Gen Physiol 1997;110:643-654.

37. Nichols CG, Shyng SL, Nestorowicz A, Glaser B, Clement JPt, Gonzalez G, Aguilar-Bryan L, Permutt MA, Bryan J. Adenosine diphosphate as an intracellular regulator of insulin secretion. Science 1996;272:1785-1787.

38. Dunne MJ, Petersen OH. Intracellular ADP activates $K_{+}$ channels that are inhibited by ATP in an insulin-secreting cell line. FEBS Lett 1986;208:59-62.

39. Conti LR, Radeke CM, Shyng SL, Vandenberg CA. Transmembrane topology of the sulfonylurea receptor SUR1. J Biol Chem 2001;276:41270-41278. Epub 2001 Aug 23
40. Pinney SE, MacMullen C, Becker S, Lin YW, Hanna C, Thornton P, Ganguly A, Shyng SL, Stanley CA. Clinical characteristics and biochemical mechanisms of congenital hyperinsulinism associated with dominant $K_{\text {ATP }}$ channel mutations. J Clin Invest 2008;118:2877-2886.

41. Cartier EA, Conti LR, Vandenberg CA, Shyng SL. Defective trafficking and function of $K_{\text {ATP }}$ channels caused by a sulfonylurea receptor 1 mutation associated with persistent hyperinsulinemic hypoglycemia of infancy. Proc Natl Acad Sci USA 2001;98:2882-2887.

42. Shyng SL, Ferrigni T, Shepard JB, Nestorowicz A, Glaser B, Permutt MA, Nichols CG. Functional analyses of novel mutations in the sulfonylurea receptor 1 associated with persistent hyperinsulinemic hypoglycemia of infancy. Diabetes 1998;47:1145-1151.

43. Tanizawa $Y$, Matsuda K, Matsuo M, Ohta Y, Ochi N, Adachi M, Koga M, Mizuno S, Kajita M, Tanaka Y, Tachibana K, Inoue H, Furukawa S, Amachi T, Ueda K, Oka Y. Genetic analysis of Japanese patients with persistent hyperinsulinemic hypoglycemia of infancy: nucleotide-binding fold-2 mutation impairs cooperative binding of adenine nucleotides to sulfonylurea receptor 1. Diabetes 2000;49:114-120.

44. Bellanne-Chantelot $C$, Saint-Martin C, Ribeiro MJ, Vaury C, Verkarre V, Arnoux JB, Valayannopoulos V, Gobrecht S, Sempoux C, Rahier J, Fournet JC, Jaubert F, Aigrain Y, Nihoul-Fekete C, de Lonlay P. ABCC8 and KCNJ11 molecular spectrum of 109 patients with diazoxide-unresponsive congenital hyperinsulinism. J Med Genet 2010;47:752-759. Epub 2010 Aug 3

45. Sempoux C, Guiot Y, Jaubert F, Rahier J. Focal and diffuse forms of congenital hyperinsulinism: the keys for differential diagnosis. Endocr Pathol 2004;15:241-246.

46. Sempoux C, Capito C, Bellanne-Chantelot C, Verkarre V, de Lonlay P, Aigrain Y, Fekete C, Guiot Y, Rahier J. Morphological mosaicism of the pancreatic islets: a novel anatomopathological form of persistent hyperinsulinemic hypoglycemia of infancy. J Clin Endocrinol Metab 2011;96:3785-3793. Epub 2011 Sep 28

47. Verkarre V, Fournet JC, de Lonlay P, Gross-Morand MS, Devillers M, Rahier J, Brunelle F, Robert JJ', Nihoul-Fekete C, Saudubray $\mathrm{JM}$, Junien C. Paternal mutation of the sulfonylurea receptor (SUR1) gene and maternal loss of 11p15 imprinted genes lead to persistent hyperinsulinism in focal adenomatous hyperplasia. J Clin Invest 1998;102:1286-1291.

48. Otonkoski T, Nanto-Salonen K, Seppanen M, Veijola R, Huopio $H$, Hussain K, Tapanainen P, Eskola O, Parkkola R, Ekstrom K, Guiot Y, Rahier J, Laakso 'M, Rintala R, Nuutila P, Minn H. Noninvasive diagnosis of focal hyperinsulinism of infancy with [18F]-DOPA positron emission tomography. Diabetes 2006:55:13-18.

49. Arbizu Lostao J, Fernandez-Marmiesse A, Garrastachu Zumarran P, Martino Casado E, Azcona San Julian C, Carracedo A, Richter Echevarria JA. [18F-fluoro-L-DOPA PET-CT imaging combined with genetic analysis for optimal classification and treatment in a child with severe congenital hyperinsulinism]. An Pediatr (Barc) 2008;68:481-485.

50. Hussain K, Flanagan SE, Smith $\mathrm{V}$, Ashworth M, Day M, Pierro A, Ellard S. An ABCC8 gene mutation and mosaic uniparental isodisomy resulting in atypical diffuse congenital hyperinsulinism. Diabetes 2008;57:259-263. Epub 2007 Oct 17

51. MacMullen $C$, Fang J, Hsu BY, Kelly A, de Lonlay-Debeney $P_{t}$ Saudubray JM, Ganguly A, Smith TJ, Stanley CA; Hyperinsulinism/hyperammonemia Contributing I. Hyperinsulinism/hyperammonemia syndrome in children with regulatory mutations in the inhibitory guanosine triphosphatebinding domain of glutamate dehydrogenase. J Clin Endocrinol Metab 2001;86:1782-1787. 
52. Palladino AA, Stanley CA. The hyperinsulinism/ hyperammonemia syndrome. Rev Endocr Metab Disord 2010;11:171-178.

53. Stanley CA, Fang J, Kutyna K, Hsu BY, Ming JE, Glaser B, Poncz M. Molecular basis and characterization of the hyperinsulinism/hyperammonemia syndrome: predominance of mutations in exons 11 and 12 of the glutamate dehydrogenase gene. HI/HA Contributing Investigators. Diabetes 2000;49:667673.

54. Stanley CA. Hyperinsulinism/hyperammonemia syndrome: insights into the regulatory role of glutamate dehydrogenase in ammonia metabolism. Mol Genet Metab 2004;81:45-51.

55. Kapoor RR, Flanagan SE, Fulton P, Chakrapani A, Chadefaux B, Ben-Omran T, Banerjee I, Shield JP, Ellard S, Hussain K. Hyperinsulinism-hyperammonaemia syndrome: novel mutations in the GLUD1 gene and genotype-phenotype correlations. Eur J Endocrinol 2009:161:731-735. Epub 2009 Aug 18

56. Kawajiri $M$, Okano $Y$, Kuno $M$, Tokuhara $D$, Hase $Y$, Inada $H$ Tashiro F, Miyazaki J, Yamano T. Unregulated insulin secretion by pancreatic beta cells in hyperinsulinism/hyperammonemia syndrome: role of glutamate dehydrogenase, ATP-sensitive potassium channel, and nonselective cation channel. Pediatr Res 2006:59:359-364.

57. Treberg JR, Clow KA, Greene KA, Brosnan ME, Brosnan JT. Systemic activation of glutamate dehydrogenase increases renal ammoniagenesis: implications for the hyperinsulinism/hyperammonemia syndrome. Am J Physiol Endocrinol Metab 2010;298:1219-1225. Epub 2010 Mar 23

58. Palladino AA, Stanley CA. The hyperinsulinism/ hyperammonemia syndrome. Rev Endocr Metab Disord 2010;11:171-178.

59. Sund NJ, Vatamaniuk MZ, Casey M, Ang SL, Magnuson MA, Stoffers DA, Matschinsky FM, Kaestner KH. Tissue-specific deletion of Foxa2 in pancreatic beta cells results in hyperinsulinemic hypoglycemia. Genes Dev 2001;15:17061715.

60. Hardy OT, Hohmeier HE, Becker TC, Manduchi E, Doliba NM, Gupta RK, White P, Stoeckert CJ Jr, Matschinsky FM, Newgard $\mathrm{CB}$, Kaestner KH. Functional genomics of the beta-cell: shortchain 3-hydroxyacyl-coenzyme $A$ dehydrogenase regulates insulin secretion independent of $\mathrm{K}+$ currents. Mol Endocrinol 2007;21:765-773. Epub 2006 Dec 21

61. Martens GA, Vervoort A, Van de Casteele M, Stange G, Hellemans K, Van Thi HV, Schuit F, Pipeleers D. Specificity in beta cell expression of L-3-hydroxyacyl-CoA dehydrogenase, short chain, and potential role in down-regulating insulin release. J Biol Chem 2007;282:21134-21144. Epub 2007 May 9

62. Li C, Chen P, Palladino A, Narayan S, Russell LK, Sayed S, Xiong G, Chen J, Stokes D, Butt YM, Jones PM, Collins HW, Cohen NA, Cohen AS, Nissim I, Smith TJ, Strauss AW, Matschinsky FM, Bennett MJ, Stanley CA. Mechanism of hyperinsulinism in short-chain 3-hydroxyacyl-CoA dehydrogenase deficiency involves activation of glutamate dehydrogenase. J Biol Chem 2010;285:31806-31818. Epub 2010 Jul 29

63. Heslegrave AJ, Kapoor RR, Eaton S, Chadefaux B, Ackay T, Simsek E, Flanagan SE, Ellard S, Hussain K. Leucine-sensitive hyperinsulinaemic hypoglycaemia in patients with loss of function mutations in 3-Hydroxyacyl-CoA Dehydrogenase. Orphanet J Rare Dis 2012;7:25.

64. Flanagan SE, Patch AM, Locke JM, Akcay T, Simsek E, Alaei M, Yekta Z, Desai M, Kapoor RR, Hussain K, Ellard S. Genome-wide homozygosity analysis reveals HADH mutations as a common cause of diazoxide-responsive hyperinsulinemic-hypoglycemia in consanguineous pedigrees. J Clin Endocrinol Metab 2011;96:498-502. Epub 2011 Jan 20
65. Pullen TJ, da Silva Xavier G, Kelsey G, Rutter GA. miR-29a and miR-29b contribute to pancreatic beta-cell-specific silencing of monocarboxylate transporter 1 (Mct1). Mol Cell Biol 2011;31:3182-3194. Epub 2011 Jun 6

66. Christesen HB, Tribble ND, Molven A, Siddiqui J, Sandal T, Brusgaard K, Ellard S, Njolstad PR, Alm J, Brock Jacobsen B, Hussain K, Gloyn AL. Activating glucokinase (GCK) mutations as a cause of medically responsive congenital hyperinsulinism: prevalence in children and characterisation of a novel GCK mutation. Eur J Endocrinol 2008:159:27-34. Epub 2008 May 1

67. Matschinsky FM. Banting Lecture 1995. A lesson in metabolic regulation inspired by the glucokinase glucose sensor paradigm. Diabetes 1996;45:223-241.

68. Cuesta-Munoz AL, Huopio H, Otonkoski T, Gomez-Zumaquero JM, Nanto-Salonen K, Rahier J, Lopez-Enriquez S, GarciaGimeno MA, Sanz P, Soriguer FC, Laakso M. Severe persistent hyperinsulinemic hypoglycemia due to a de novo glucokinase mutation. Diabetes 2004;53:2164-2168.

69. Hussain K. Insights in congenital hyperinsulinism. Endocr Dev 2007;11:106-121.

70. Kapoor RR, Heslegrave A, Hussain K. Congenital hyperinsulinism due to mutations in HNF4A and HADH. Rev Endocr Metab Disord 2010;11:185-191.

71. Flanagan SE, Kapoor RR, Mali G, Cody D, Murphy N, Schwahn B, Siahanidou T, Banerjee I, Akcay T, Rubio-Cabezas O, Shield JP, Hussain K, Ellard S. Diazoxide-responsive hyperinsulinemic hypoglycemia caused by HNF4A gene mutations. Eur J Endocrinol 2010;162:987-992. Epub 2010 Feb 17

72. Conn JJ, Simm PJ, Oats JJ, Nankervis AJ, Jacobs SE, Ellard S, Hattersley AT. Neonatal hyperinsulinaemic hypoglycaemia and monogenic diabetes due to a heterozygous mutation of the HNF4A gene. Aust N Z J Obstet Gynaecol 2009;49:328-330.

73. Black $M H$, Fingerlin $T E$, Allayee $H$, Zhang $W$, Xiang $A H$, Trigo $E$, Hartiala J, Lehtinen AB, Haffner SM, Bergman RN, McEachin RC, Kjos SL, Lawrence JM, Buchanan TA, Watanabe RM. Evidence of interaction between PPARG2 and HNF4A contributing to variation in insulin sensitivity in Mexican Americans. Diabetes 2008:57:1048-1056. Epub 2007 Dec 27

74. Samuk I, Afriat R, Horne T, Bistritzer T, Barr J, Vinograd I. Dumping syndrome following Nissen fundoplication, diagnosis, and treatment. J Pediatr Gastroenterol Nutr 1996;23:235-240.

75. Palladino AA, Sayed S, Levitt Katz LE, Gallagher PR, De Leon DD. Increased glucagon-like peptide-1 secretion and postprandial hypoglycemia in children after Nissen fundoplication. J Clin Endocrinol Metab 2009;94:39-44. Epub 2008 Oct 28

76. Ng DD, Ferry RJ, Jr., Kelly A, Weinzimer SA, Stanley CA, Katz LE. Acarbose treatment of postprandial hypoglycemia in children after Nissen fundoplication. J Pediatr 2001;139:877-879.

77. Service FJ, Natt N, Thompson GB, Grant CS, van Heerden JA, Andrews JC, Lorenz E, Terzic A, Lloyd RV. Noninsulinoma pancreatogenous hypoglycemia: a novel syndrome of hyperinsulinemic hypoglycemia in adults independent of mutations in Kir6.2 and SUR1 genes. J Clin Endocrinol Metab 1999:84:1582-1589.

78. Foster-Schubert KE. Hypoglycemia complicating bariatric surgery: incidence and mechanisms. Curr Opin Endocrinol Diabetes Obes 2011;18:129-133.

79. Edidin DV, Farrell EE, Gould VE. Factitious hyperinsulinemic hypoglycemia in infancy: diagnostic pitfalls. Clin Pediatr (Phila) 2000;39:117-119.

80. Giurgea I, Ulinski T, Touati G, Sempoux C, Mochel F, Brunelle F, Saudubray JM, Fekete C, de Lonlay P. Factitious hyperinsulinism leading to pancreatectomy: severe forms of Munchausen syndrome by proxy. Pediatrics 2005;116:145-148. 
81. Ludwig A, Ziegenhorn K, Empting S, Meissner T, Marquard J, Holl R; Diabetes Patienten-Verlaufsdokumentationssystem (DPV) Group, Mohnike K. Glucose metabolism and neurological outcome in congenital hyperinsulinism. Semin Pediatr Surg 2011:20:45-49.

82. Cornblath M, Hawdon JM, Williams AF, Aynsley-Green A, WardPlatt MP, Schwartz R, Kalhan SC. Controversies regarding definition of neonatal hypoglycemia: suggested operational thresholds. Pediatrics 2000;105:1141-1145.

83. Hussain K, Aynsley-Green A, Stanley CA. Medications used in the treatment of hypoglycemia due to congenital hyperinsulinism of infancy (HI). Pediatr Endocrinol Rev 2004:2:163-167.

84. Moens K, Berger V, Ahn JM, Van Schravendijk C, Hruby VJ, Pipeleers D, Schuit F. Assessment of the role of interstitial glucagon in the acute glucose secretory responsiveness of in situ pancreatic beta-cells. Diabetes 2002;51:669-675.

85. Kane C, Lindley KJ, Johnson PR, James RF, Milla PJ, AynsleyGreen A, Dunne MJ. Therapy for persistent hyperinsulinemic hypoglycemia of infancy. Understanding the responsiveness of beta cells to diazoxide and somatostatin. J Clin Invest 1997;100:1888-1893.

86. Glaser B, Landau H, Smilovici A, Nesher R. Persistent hyperinsulinaemic hypoglycaemia of infancy: long-term treatment with the somatostatin analogue Sandostatin. Clin Endocrinol (Oxf) 1989;31:71-80.

87. Laje P, Halaby L, Adzick NS, Stanley CA. Necrotizing enterocolitis in neonates receiving octreotide for the management of congenital hyperinsulinism. Pediatr Diabetes 2010;11:142-147. Epub 2009 Jun 25

88. Le Quan Sang KH, Arnoux JB, Mamoune A, Saint-Martin C, Bellanne-Chantelot C, Valayannopoulos V, Brassier A, Kayirangwa H, Barbier V, Broissand C, Fabreguettes JR, Charron $\mathrm{B}$, Thalabard JC, de Lonlay P. Successful treatment of congenital hyperinsulinism with long-acting release octreotide. Eur J Endocrinol 2012;166:333-339. Epub 2011 Nov 2

89. Modan-Moses D, Koren I, Mazor-Aronovitch K, Pinhas-Hamiel O, Landau $\mathrm{H}$. Treatment of congenital hyperinsulinism with lanreotide acetate (Somatuline Autogel). J Clin Endocrinol Metab 2011:96:2312-2317. Epub 2011 Jun 22

90. Hussain K. Diagnosis and management of hyperinsulinaemic hypoglycaemia of infancy. Horm Res 2008;69:2-13. Epub 2007 Dec 4

91. Mohnike K, Blankenstein O, Christesen HT, De Lonlay J, Hussain K, Koopmans KP, Minn H, Mohnike W, Mutair A, Otonkoski T, Rahier J, Ribeiro M, Schoenle E, Fekete CN. Proposal for a standardized protocol for 18F-DOPA-PET (PET/CT) in congenital hyperinsulinism. Horm Res 2006;66:40-42. Epub 2006 May 19
92. Patterson ME, Mao CS, Yeh MW, Ipp E, Cortina G, Barank D, Vasinrapee P, Pawlikowska-Haddal A, Lee WN, Yee JK. Hyperinsulinism presenting in childhood and treatment by conservative pancreatectomy. Endocr Pract 2012;18:52-56.

93. Pierro A, Nah SA. Surgical management of congenital hyperinsulinism of infancy. Semin Pediatr Surg 2011;20:50-53.

94. Hardy OT, Hernandez-Pampaloni M, Saffer JR, Scheuermann JS, Ernst LM, Freifelder R, Zhuang H, MacMullen C, Becker S, Adzick NS, Divgi C, Alavi A, Stanley CA. Accuracy of [18F]fluorodopa positron emission tomography for diagnosing and localizing focal congenital hyperinsulinism. J Clin Endocrinol Metab 2007;92:4706-4711. Epub 2007 Sep 25

95. Subramaniam RM, Karantanis D, Peller PJ. [18F]Fluoro-L-dopa $\mathrm{PET} / \mathrm{CT}$ in congenital hyperinsulinism. J Comput Assist Tomogr 2007;31:770-772.

96. Ribeiro MJ, Boddaert $N$, Delzescaux $T$, Valayannopoulos $V$, Bellanne-Chantelot $C$, Jaubert F, Verkarre V, Nihoul-Fekete C, Brunelle F, De Lonlay P. Functional imaging of the pancreas: the role of [18F]fluoro-L-DOPA PET in the diagnosis of hyperinsulinism of infancy. Endocr Dev 2007;12:55-66.

97. Bax KN, van der Zee DC. The laparoscopic approach toward hyperinsulinism in children. Semin Pediatr Surg 2007; 16:245-251.

98. Barthlen W, Blankenstein O, Mau H, Koch M, Hohne C, Mohnike W, Eberhard T, Fuechtner F, Lorenz-Depiereux B, Mohnike K. Evaluation of [18F]fluoro-L-DOPA positron emission tomography-computed tomography for surgery in focal congenital hyperinsulinism. J Clin Endocrinol Metab 2008;93:869-875. Epub 2007 Dec 11

99. Capito C, Khen-Dunlop N, Ribeiro MJ, Brunelle F, Aigrain $Y$, Cretolle $C$, Jaubert F, De Lonlay P, Nihoul-Fekete C. Value of 18Ffluoro-L-dopa PET in the preoperative localization of focal lesions in congenital hyperinsulinism. Radiology 2009;253:216-222. Epub 2009 Aug 25

100. Bax KN, van der Zee DC. The laparoscopic approach toward hyperinsulinism in children. Semin Pediatr Surg 2007;16:245251.

101. Lovvorn HN 3rd, Nance ML, Ferry RJ, Jr., Stolte L, Baker L, O'Neill JA Jr, Schnaufer L, Stanley CA, Adzick NS. Congenital hyperinsulinism and the surgeon: lessons learned over 35 years. J Pediatr Surg 1999;34:786-792; discussion 792-783.

102. Modan-Moses D, Koren I, Mazor-Aronovitch K, Pinhas-Hamiel $\mathrm{O}$, Landau $\mathrm{H}$. Treatment of congenital hyperinsulinism with lanreotide acetate (Somatuline Autogel). J Clin Endocrinol Metab 2011;96:2312-2317. Epub 2011 Jun 22 